\title{
Role of Warming in Destabilization of Intrapermafrost Gas Hydrates in the Arctic Shelf: Experimental Modeling
}

\author{
Evgeny Chuvilin ${ }^{1, *(\mathbb{D}}$, Dinara Davletshina ${ }^{1,2}$, Valentina Ekimova ${ }^{1}$, Boris Bukhanov ${ }^{1}(\mathbb{D}$, \\ Natalia Shakhova ${ }^{3,4}$ and Igor Semiletov ${ }^{3,5,6}$ \\ 1 Skolkovo Institute of Science and Technology (Skoltech), 121205 Moscow, Russia; \\ D.Davletshina@skoltech.ru (D.D.); Valentina.Ekimova@skoltech.ru (V.E.); B.Bukhanov@skoltech.ru (B.B.) \\ 2 GSP-1, Lomonosov Moscow State University (MSU), 119991 Moscow, Russia \\ 3 National Research Tomsk Polytechnic University, Tomsk Polytechnic University (TPU), 634050 Tomsk, \\ Russia; shahova@tpu.ru (N.S.); ipsemiletov@alaska.edu (I.S.) \\ 4 International Arctic Research Center, University Alaska Fairbanks, Fairbanks, AK 99775, USA \\ 5 Pacific Oceanological Institute, Far Eastern Branch of Russian Academy of Sciences, \\ 690041 Vladivostok, Russia \\ 6 Moscow Institute of Physics and Technology, 141701 Moscow Region, Russia \\ * Correspondence: e.chuvilin@skoltech.ru
}

Received: 2 September 2019; Accepted: 18 September 2019; Published: 20 September 2019

\begin{abstract}
Destabilization of intrapermafrost gas hydrates is one of the possible mechanisms responsible for methane emission in the Arctic shelf. Intrapermafrost gas hydrates may be coeval to permafrost: they originated during regression and subsequent cooling and freezing of sediments, which created favorable conditions for hydrate stability. Local pressure increase in freezing gas-saturated sediments maintained gas hydrate stability from depths of 200-250 m or shallower. The gas hydrates that formed within shallow permafrost have survived till present in the metastable (relict) state. The metastable gas hydrates located above the present stability zone may dissociate in the case of permafrost degradation as it becomes warmer and more saline. The effect of temperature increase on frozen sand and silt containing metastable pore methane hydrate is studied experimentally to reconstruct the conditions for intrapermafrost gas hydrate dissociation. The experiments show that the dissociation process in hydrate-bearing frozen sediments exposed to warming begins and ends before the onset of pore ice melting. The critical temperature sufficient for gas hydrate dissociation varies from $-3.0^{\circ} \mathrm{C}$ to $-0.3^{\circ} \mathrm{C}$ and depends on lithology (particle size) and salinity of the host frozen sediments. Taking into account an almost gradientless temperature distribution during degradation of subsea permafrost, even minor temperature increases can be expected to trigger large-scale dissociation of intrapermafrost hydrates. The ensuing active methane emission from the Arctic shelf sediments poses risks of geohazard and negative environmental impacts.
\end{abstract}

Keywords: Arctic shelf; permafrost; gas hydrate; temperature increase; hydrate dissociation; methane emission; environmental impact; geohazard

\section{Introduction}

A wealth of data on subsea permafrost in the Arctic shelf collected through Russian and international research projects [1-15] has revealed large-scale methane emission from bottom sediments into water and on into the atmosphere. The gases in the Arctic shelf are often attributed to increasing microbial methane generation, migration of gas through taliks and faults, as well as to decomposition of intrapermafrost and subpermafrost gas hydrates during progressive degradation of subsea 
permafrost [11,16-21]. The dissociation of hydrates related to subsea permafrost degradation has been largely discussed lately as the main mechanism maintaining the emanation of methane $[4,14,18,22-26]$.

Gas hydrates (clathrates) are metastable ice- or snow-like solid compounds that form from water and low-molecular gas under certain pressures and temperatures $[27,28]$. One cubic meter of clathrate can store about 160 cubic meters of gas. Natural hydrates of gas (mainly methane) can be stable in marine sediments and in permafrost [29] and occur in the Arctic shelf below $250 \mathrm{~m}$ or $300 \mathrm{~m}$ [30,31]. Relict metastable hydrates can survive also at shallower depths in the Arctic subsea permafrost due to self-preservation [32]. Shallow intrapermafrost metastable gas hydrates are especially sensitive to environment changes leading to pressure decrease, temperature increase, and migration of salts [33].

The extent and structure of subsea permafrost in the Russian Arctic shelf remain poorly constrained because of drilling shortage. Some knowledge is available for the western Arctic sector from test boreholes and geophysical surveys [7,34], but the data from the eastern sector are limited to sporadic findings of shelf permafrost, most often by geophysical methods [35]. The Arctic shelf permafrost has been mapped recently with reference to modeling results, well log and core data, and geophysical surveys [36-41]. The modeling predicts that the Arctic shelf permafrost may be as thick as $700 \mathrm{~m}$, which is favorable for the formation and preservation of intra- and subpermafrost gas hydrates $[4,26,42,43]$.

The relation of methane emanation from bottom sediments with the presence of gas hydrates is known from different Arctic regions (Svalbard Archipelago, Norwegian Sea, Beaufort Sea, etc.). Gas flares up to $850 \mathrm{~m}$ high and $400 \mathrm{~m}$ thick were reported from areas of gas hydrate accumulation in the Angola basin west of Spitsbergen Island [44,45]. There is evidence of gas eruptions, anomalous phytoplankton abundances, bubbling in water, and meters-size pockmarks [14] in bottom sediments of the Norwegian Sea (Vestnes, Storegga, and Nyegga areas) [30,46]. Pingo-like cone-shaped edifices at gas vents on the bottom of the southern Beaufort Sea first described by [47] may result from gas hydrate dissociation caused by degradation of shelf permafrost rather than being associated with seeps from subbottom gas reservoirs as suggested by Paull and Sparrow [15,47]. More evidence of gas emanation in the Arctic shelf comes from Bennet Island and the Mackenzie delta where gas hydrates may occur both beneath and within permafrost [30,46,48-53].

Paleoclimate reconstructions and modeling of permafrost thickness dynamics indicate that gas hydrates in the subsea permafrost of the eastern Arctic sector formed simultaneously with the latter during Late Pliocene-Pleistocene regression about 20-25 kyr BP [37]. They could form at shallow depths within permafrost at favorable thermobaric conditions the emerged sediments became frozen, and then survived in the metastable state for a long time due to the self-preservation effect after the pressure and temperature had changed. The onshore permafrost became submerged during subsequent transgression which led to its warming and degradation both from below (by heat flux through the sea bottom) and from above (by interaction with sea water) [39]. Penetration of sea water and dissolved salts into frozen sediments [33] and increase in their temperature [4,38,41,54] apparently destabilized the intrapermafrost gas hydrates.

Warming of subsea permafrost triggers decomposition of intrapermafrost gas hydrates into gas (methane) and ice. The reaction consumes much of the heat and the sediments cool down, which prevents them from further thawing. Thus, the presence of intrapermafrost gas hydrates may account for the persistence of permafrost in the Arctic shelf and for the gradientless temperature distribution observed in some boreholes in the Laptev shelf [4]. The liberated methane passes into sea water, sinks to the bottom, and becomes a source of gas emission [26].

However, the thawing of frozen hydrate-bearing rocks and related dissociation of hydrates, which can maintain self-cooling of the sediments, remains poorly studied. In this respect, experimental modeling of the mechanism and patterns of pore gas hydrate dissociation induced by permafrost warming may shed light on destabilization of intrapermafrost gas hydrates and hazardous emission of methane in the Arctic shelf. 


\section{Methods}

The effect of temperature on the dissociation of pore gas hydrates in frozen sediments was studied experimentally using a specially designed system (Figure 1) which can reproduce thermobaric conditions in a large range of temperatures and pressures. The system, with a working volume of $\sim 420 \mathrm{~cm}^{3}$, consists of a pressure cell that accommodates a metal container with samples; an analog-digital converter (ADC); and a personal computer (PC) for saving records of pressure and temperature changes [55]. The temperature was maintained, to an accuracy of $0.1{ }^{\circ} \mathrm{C}$, by circulation of liquid from the HAAKE Phoenix C40P refrigerated bath along the "thermal coat" around the pressure cell. During our experiments, the temperature and pressure in the cell were accurate to $0.05{ }^{\circ} \mathrm{C}$ and $0.005 \mathrm{MPa}$, respectively.

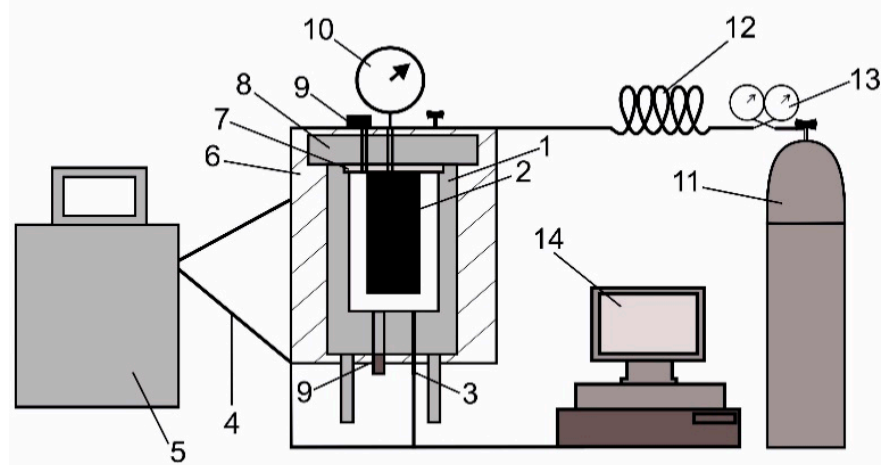

Figure 1. Sketch of experimental setup for modeling the dissociation of pore gas hydrates. $\mathbf{1}=$ pressure cell; $\mathbf{2}$ = container with soil samples; $\mathbf{3}=$ thermistor input sleeve; $\mathbf{4}=$ hose for circulating liquid; $\mathbf{5}=$ refrigerated bath; $\mathbf{6}=$ thermal coat; $\mathbf{7}=$ tephlon gasket; $\mathbf{8}=$ steel lid; $\mathbf{9}=$ pressure sensors; $\mathbf{1 0}=$ digital pressure gauge; $\mathbf{1 1}=$ gas bomb; $\mathbf{1 2}=$ gas tube; $\mathbf{1 3}=$ pressure regulator; $\mathbf{1 4}=\mathrm{PC}$ with $\mathrm{ADC}$.

To simulate the dissociation of pore gas hydrates, natural deformed soil samples of sand, silt, and clay silt (Table 1) were saturated with hydrate. The constituent minerals in the samples were identified by X-ray diffractometer ULTIMA-IV (Rigaku company, Tokyo, Japan), salinity was determined through water extracts from dry sediment samples, and the particle size distribution (Table 2) was determined following the procedure of State Standard [56].

Table 1. Mineralogy and salinity of soil samples.

\begin{tabular}{ccccc}
\hline Sample & Sampling Site & \multicolumn{2}{c}{ Mineralogy, \% } & Salinity, \% \\
\hline \multirow{3}{*}{ Sand } & Arctic shelf & Quartz & 55 & \\
& (Buor Khaya Bay) & Albite & 18 & 0.4 \\
& Microcline & 9 & \\
& & Quartz & 42.5 & \\
Silt & Arctic shelf & Albite & 14.9 & 0.1 \\
& (Buor Khaya Bay) & Illite & 9.1 & \\
& & Chlorite & 6.9 & \\
& & Microcline & 5.9 & \\
& & Hydromica & 3.9 & 0.7 \\
& & Quartz & 46.4 & \\
Clay silt & South Tambei GCF & Albite & 25.3 & \\
& & Chlorite & 10.4 & \\
& & Mirror stone & 7.4 & \\
& & Orthoclase & 6.5 & \\
& & Kaolinite & 4.2 & \\
\hline
\end{tabular}

Note: GCF = gas-condensate field. The listed mineral phases have percentages $>1 \%$. 
Table 2. Particle size distribution in soil samples.

\begin{tabular}{ccccc}
\hline \multirow{2}{*}{ Sample } & \multicolumn{3}{c}{ Particle Size Distribution, \% } & \multirow{2}{*}{ Lithology * } \\
\cline { 2 - 4 } & $\mathbf{1 - 0 . 0 5} \mathbf{~} \mathbf{m}$ & $\mathbf{0 . 0 5}-\mathbf{0 . 0 0 1} \mathbf{~ m m}$ & $<\mathbf{0 . 0 0 1} \mathbf{~ m m}$ & \\
\hline Sand & 96.7 & 2.0 & 1.3 & Fine sand \\
Silt & 63.4 & 32.6 & 4.0 & Silty sand \\
Clay silt & 21.1 & 55.8 & 23.1 & Clay silt (loam) \\
\hline
\end{tabular}

Note: * Lithology is according to classifications of E. Sergeev (sand) and V. Okhotin (silt and loam).

Samples were prepared from air-dry soil mixed with distilled water and crushed ice (in the case of silt) and left for $30 \mathrm{~min}$ at room temperature to achieve the wanted moisture content. The wet soil was compacted layer-by-layer in a cylindrical container $(10 \mathrm{~cm}$ high and $4.6 \mathrm{~cm}$ in diameter $)$ and placed into a pressure cell. The pressure cell with the samples was sealed tightly, vacuumed, frozen to $-5-6{ }^{\circ} \mathrm{C}$, and then filled with hydrate-forming gas $\left(99.98 \% \mathrm{CH}_{4}\right)$ at $4-6 \mathrm{MPa}[55,57]$. Pore hydrate accumulation was stimulated by cyclic freezing and thawing of the samples at above-equilibrium pressure.

Once hydrate formation in the samples decayed, the time-dependent kinetics of pore hydrate accumulation and phase transition parameters were analyzed by the pressure-volume-temperature (PVT) method [55].

The volume content of hydrate $(H v, \%)$ was found as:

$$
H_{v}=\frac{M_{h} \cdot \rho}{M_{S} \cdot \rho_{h}} \cdot 100 \%
$$

where $M h$ is the weight of pore gas hydrate $(\mathrm{g})$; $M s$ is the weight of soil sample $(\mathrm{g})$; is the sample density $\left(\mathrm{g} / \mathrm{cm}^{3}\right) ; h$ is the skeleton (hydrate) density of empty square lattice (without gas molecules by analogy with the pure ice structure); $h$ for $\mathrm{CH}_{4}$ was assumed to be $0.794 \mathrm{~g} / \mathrm{cm}^{3}$ [55].

Hydrate saturation or percentage of pore space filled with hydrate $(S h, \%)$ was inferred from the volume content of hydrate as:

$$
S_{h}=\frac{H_{v}}{n}
$$

where $n$ is the sample porosity (u.f.), assuming a hydrate number of 5.9 for $\mathrm{CH}_{4}$.

The fraction of water converted to hydrate, or hydrate coefficient $(K h, u . f$.$) was found as:$

$$
K_{h}=\frac{W_{h}}{W}
$$

where $W h$ is the percentage of water converted to hydrate (\% of dry sample weight) and $W$ is the total amount of moisture (initial water content, \%).

Then the frozen soil samples saturated with methane hydrate to a known level were exposed to non-equilibrium conditions at a constant negative temperature of $-6{ }^{\circ} \mathrm{C}$, by decreasing pressure in the cell to $0.6-1.6 \mathrm{MPa}$. These pressure and temperature conditions correspond to those in natural sediments at gas emanation sites. Pore gas hydrates underwent dissociation at a decaying rate because of the self-preservation effect [32]. The pressure in the cell was maintained at a constant low level by slow gas release as the pressure increased. Once the pore gas hydrates reached the metastable state, the self-preservation coefficient $(K s c)$ was calculated as a ratio of residual hydrate content in a frozen sample at below-equilibrium pressure to the initial hydrate content. At the next step, the temperature in the cell was increased for a few hours from the initial value $-5^{\circ} \mathrm{C}$ to $+6{ }^{\circ} \mathrm{C}$. The recorded time-dependent temperature and pressure changes were used to calculate the volume of releasing methane per $1 \mathrm{~m}^{3}$ of thawing hydrate-bearing soil. 


\section{Experimental Results}

The soil samples, which were saturated with methane hydrate in laboratory and exposed to the self-preservation conditions by decreasing the pressure to below equilibrium (Table 3), showed variations during the experiment caused by dissociation of pore gas hydrates.

Table 3. Hydrate saturation in frozen hydrate-saturated samples.

\begin{tabular}{|c|c|c|c|c|c|c|c|}
\hline \multirow{3}{*}{ Sample } & \multirow{3}{*}{$\begin{array}{c}\text { Water } \\
\text { Content, \% }\end{array}$} & \multirow{3}{*}{ Density, $\mathrm{g} / \mathrm{cm}^{3}$} & \multicolumn{5}{|c|}{ Hydrate Saturation } \\
\hline & & & \multicolumn{2}{|c|}{ Equilibrium } & \multicolumn{3}{|c|}{ Self-Preservation } \\
\hline & & & Sh initial, \% & $K h$ initial, u.f. & Sh final, \% & $K h$ final, u.f. & $K s c, \%$ \\
\hline Sand & 14 & 1.80 & 47 & 0.59 & 4 & 0.05 & 8.5 \\
\hline Silt & 15 & 1.82 & 25 & 0.29 & 6.9 & 0.05 & 26 \\
\hline Loam & 18 & 1.20 & 11.5 & 0.29 & 7 & 0.17 & 61 \\
\hline
\end{tabular}

The highest percentage of pore hydrate was measured in sand $(S h=47 \%)$, while the fraction of water converted to hydrate $(K h)$ was $59 \%$; the silt and clay silt samples showed lower respective values: $25 \%$ and $11.5 \%$ for $S h$ and $<29 \%$ for $K h$. The pressure decrease to below equilibrium led to partial dissociation and self-preservation of pore hydrate recorded in saturation decrease [32]. At the end of the dissociation process, the frozen samples contained $4-7 \%$ of residual hydrate. The self-preservation coefficient $(\mathrm{Ksc})$ was the highest in clay silt $(61 \%)$ and the lowest in sand $(8.5 \%)$.

The frozen soil samples with metastable pore methane hydrate were heated to estimate the effect of warming on hydrate destabilization detectable in the time-dependent change of pressure, temperature, and hydrate coefficient (Figures 2-4). In addition, temperature corresponding to the onset of rapid pore hydrate dissociation $\left(t_{d}\right)$ was determined for each experiment by the intersection of the tangents to the dramatic bend of the hydrate coefficient graph (blue line) and temperature graph (red line).

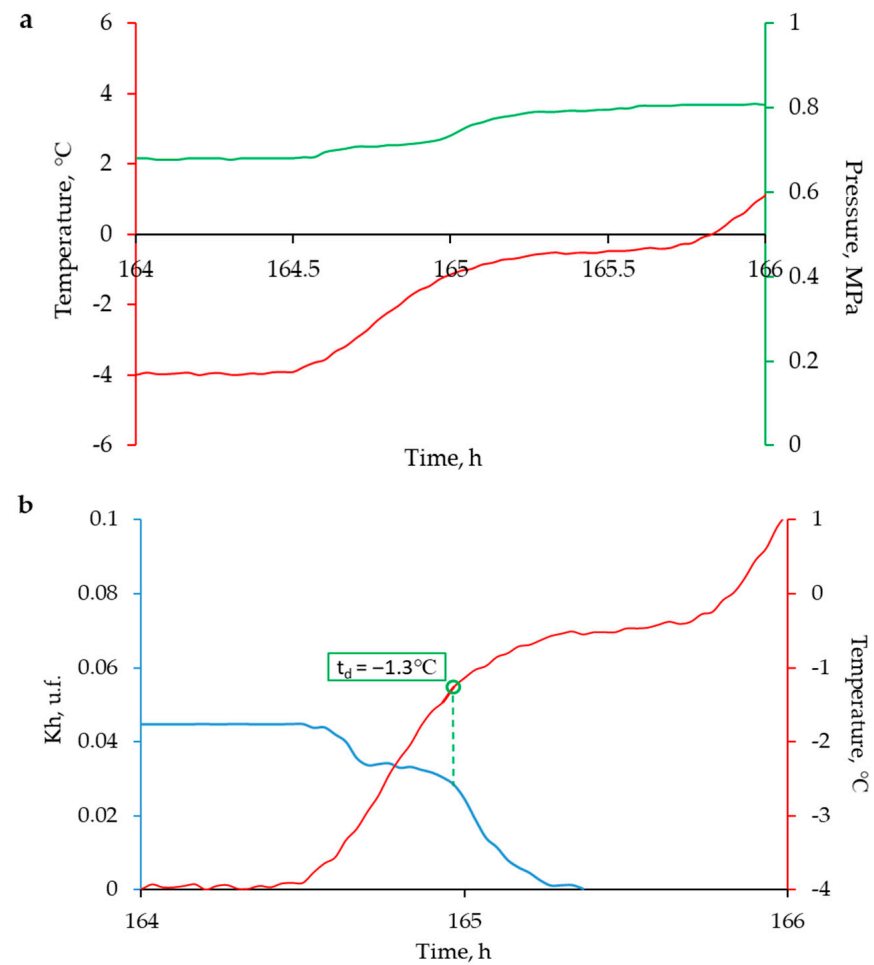

Figure 2. Time-dependent change of temperature and pressure (a), and hydrate coefficient $(K h)(\mathbf{b})$ in frozen hydrate-bearing sand exposed to warming. $t_{d}$ is the temperature corresponding to the onset of rapid pore hydrate dissociation. 

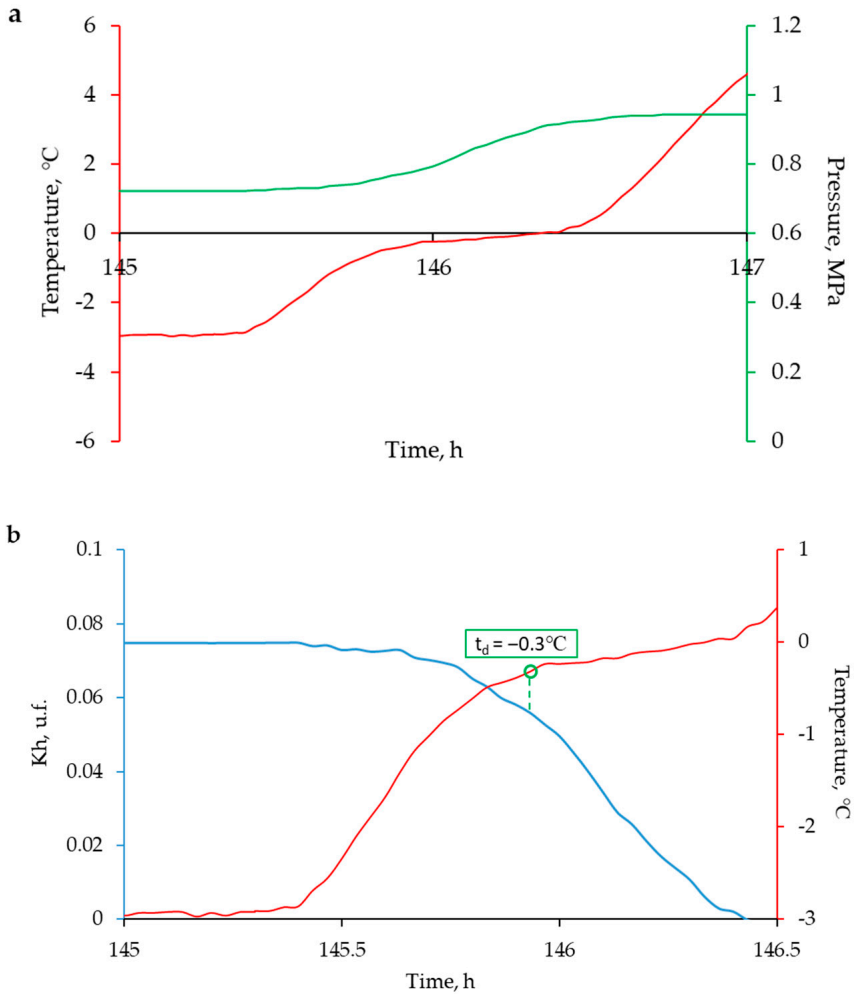

Figure 3. Time-dependent change of temperature and pressure (a), and hydrate coefficient $(K h)(\mathbf{b})$ in frozen hydrate-bearing silt exposed to warming. $t_{d}$ is the temperature corresponding to the onset of rapid pore hydrate dissociation.

a
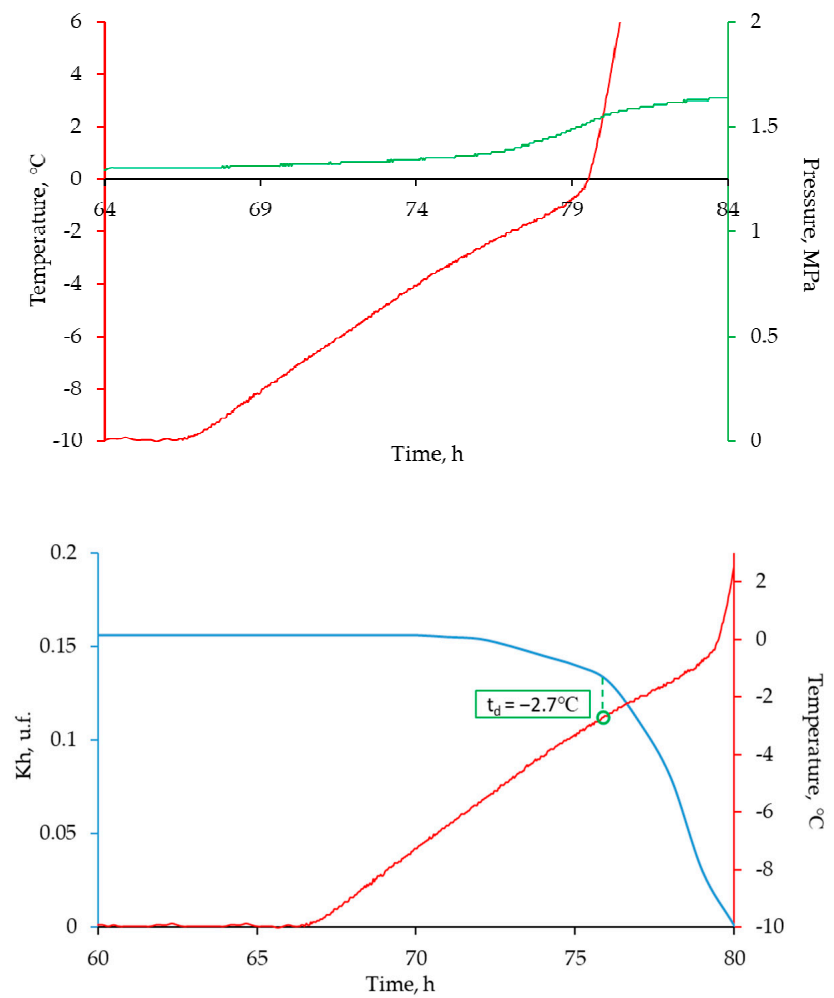

Figure 4. Time-dependent change of temperature and pressure (a), and hydrate coefficient $(K h)(\mathbf{b})$ in frozen hydrate-bearing clay silt exposed to warming. $t_{d}$ is the temperature corresponding to the onset of rapid pore hydrate dissociation. 
In the beginning of the temperature increase, the pressure in the cell became slightly $(0.02-0.03 \mathrm{MPa})$ higher as a result of gas expansion, but then increased markedly upon dissociation of pore methane hydrate. The increase was $0.1 \mathrm{MPa}$ for the sand sample, $0.15 \mathrm{MPa}$ for silt, and $0.2 \mathrm{MPa}$ for clay silt. Rapid dissociation of pore hydrate in the frozen samples began at different temperatures (Figure $2 \mathrm{~b}$, Figure $3 b$, Figure $4 b$ ): $t_{d}$ was $-1.3{ }^{\circ} \mathrm{C}$ in sand (Figure $2 b$ ), $-0.3{ }^{\circ} \mathrm{C}$ in silt (Figure $3 b$ ), and $-2.7{ }^{\circ} \mathrm{C}$ in clay silt (Figure $4 \mathrm{~b}$ ). These $t_{d}$ values remained in the range of negative temperatures below the pore ice-water phase transition (melting point). The $t_{d}$ temperature was the highest in non-saline silt $\left(-0.3{ }^{\circ} \mathrm{C}\right)$ and shifted to lower values as salinity increased in the series 'silt-sand-clay silt' (Figure 5). Thus, the dissociation temperature of metastable pore hydrate is lower in saline and fine-grained soils than in coarser and less saline ones. Quite low $t_{d}$ values (about $-6.6^{\circ} \mathrm{C}$ ) were obtained for highly saline clay ( $\mathrm{Z}$ up to $1.8 \%$ ) sampled in the Yamal Peninsula near the Bovanenkovo gas and condensate field. Therefore, gas hydrates may have existed at colder conditions in the past but failed to survive as the permafrost temperature increased to about $-3^{\circ} \mathrm{C}[58]$.

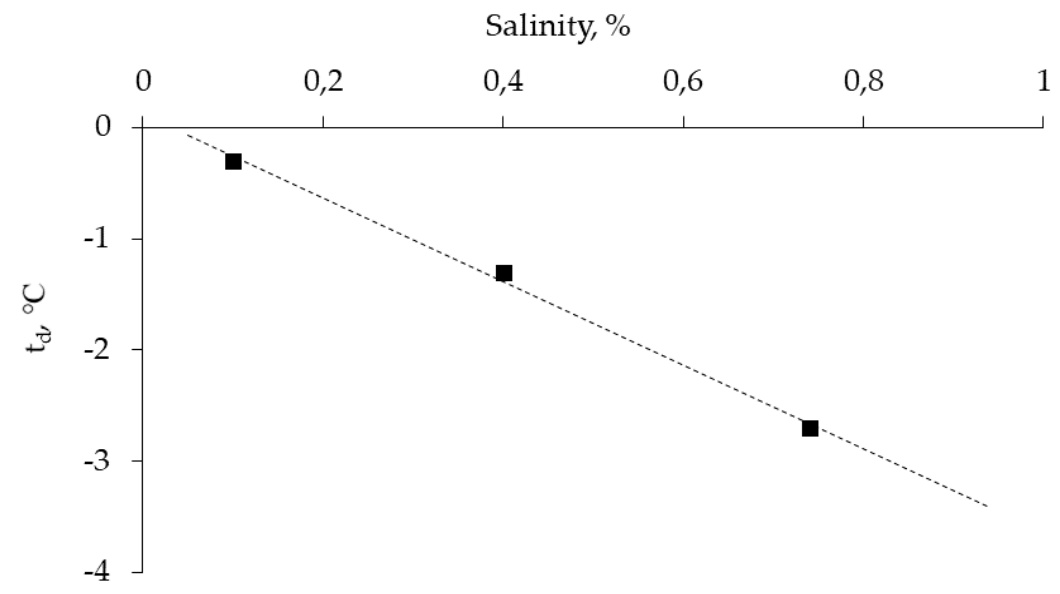

Figure 5. Temperature of rapid hydrate dissociation onset $\left(t_{d}\right)$ in frozen hydrate-bearing samples as a function of salinity.

\section{Discussion}

The experimentally revealed behavior of pore gas hydrates in samples exposed to increasing temperatures has implications for the conditions of preservation and dissociation of gas hydrates in the Arctic shelf permafrost. This knowledge is of special interest for the eastern Arctic sector (Laptev shelf), where subsea permafrost is widespread and thick $(600 \mathrm{~m})$ and voluminous methane emission may result from dissociation of intrapermafrost gas hydrates. The composition and temperature of the permafrost in the area are poorly constrained for the lack of explicit geological evidence but the origin and evolution of shelf permafrost, as well as the local conditions for gas hydrate stability, were predicted by modeling [59-61].

The modeling results predict the following history of permafrost in the Arctic shelf. It formed during regression about $20-15 \mathrm{kyr} \mathrm{BP}$ as the emerged rocks became exposed to prolonged cooling [40], which produced a zone of gas hydrate stability both beneath and within the permafrost. The pore gas present in freezing sediments could partly convert to hydrate, including at depths shallower than $200 \mathrm{~m}$ [55]. The permafrost at that time had a temperature of $-13{ }^{\circ} \mathrm{C}$ or $-12{ }^{\circ} \mathrm{C}$ and its thickness reached $700 \mathrm{~m}$ or more $[42,62,63]$. The subsea permafrost gradually warmed up during the subsequent transgression (about $9 \mathrm{kyr} \mathrm{BP}$ ) and has reached a temperature of $-2{ }^{\circ} \mathrm{C}$ to $-1.5^{\circ} \mathrm{C}$ by present. Note that the temperature field has almost no gradient [40]. The temperature increase led to progressive degradation of the permafrost and destabilization of pore gas hydrates, including those in the metastable state. As shown by experiments, the destabilization begins at a certain temperature controlled by the lithology (particle size) and salinity of sediments. 
The available published evidence and experimental results allow sketching a scenario of changes in warming subsea permafrost that contains relict metastable pore gas hydrates (Figure 6).
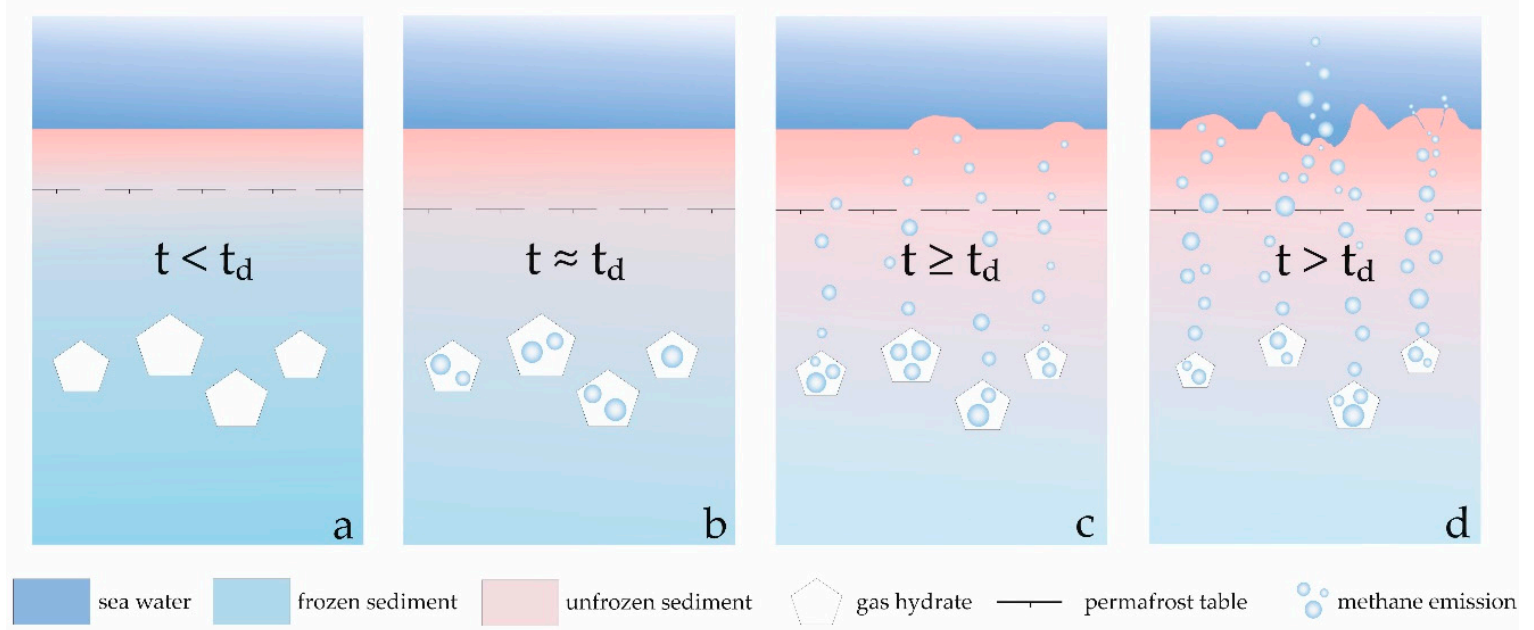

Figure 6. Evolution of hydrate-bearing subsea permafrost exposed to progressive temperature increase (a, b, c, d- details below in text).

In the beginning of transgression, the temperature of permafrost increases upon interaction with sea water. Metastable intrapermafrost gas hydrates hold as long as this temperature remains below the critical value $t_{d}$ (Figure 6a) but begin to dissociate once the permafrost reaches the $t_{d}$ level (Figure 6b). Gas hydrates dissociate and the liberated methane begins to rise toward the sea bottom and causes swelling of sediments while the permafrost temperature is equal to or slightly above the $t_{d}$ level (Figure 6c). Finally, when the permafrost exceeds the critical temperature, rapid dissociation of gas hydrates can produce active methane emission and water bubbling detectable by acoustic emission survey [21], and pockmarks, sinkholes, and other efflux structures form on the sea bottom (Figure 6d).

The laboratory results place constraints on the amount of methane that can emit from permafrost containing metastable gas hydrates: $1 \mathrm{~m}^{3}$ of frozen samples exposed to warming can release $1.5 \mathrm{~m}^{3}$ to $5.5 \mathrm{~m}^{3}$ of methane (Table 4 ).

Table 4. Amount of methane $\left(\mathrm{CH}_{4}\right)$ released upon warming of frozen hydrate-bearing samples.

\begin{tabular}{ccc}
\hline Sample & Sh $\mathbf{d .}, \boldsymbol{\%}$ & $\mathbf{C H}_{\mathbf{4}}$ Emission $\left.\mathbf{( m}^{\mathbf{3}}\right)$ from $\mathbf{1} \mathbf{~ m}^{\mathbf{3}}$ of Thawing Hydrate-Bearing Rock \\
\hline Sand & 2.3 & 1.5 \\
Silt & 4.8 & 3.2 \\
Clay silt & 5.3 & 5.5 \\
\hline
\end{tabular}

Since the critical temperature of the hydrate dissociation onset depends on lithology (pore size) and salinity of the host sediments, gas hydrates in heterogeneous subsea permafrost may exist in layers with different $t_{d}$ temperatures. A part of accumulated gas hydrates can dissociate early during transgression at moderate permafrost warming $\left(-3^{\circ} \mathrm{C}\right.$ to $\left.-5^{\circ} \mathrm{C}\right)$, but some may hold at the present temperature level of relatively warm permafrost $\left(-1{ }^{\circ} \mathrm{C}\right.$ to $\left.-2{ }^{\circ} \mathrm{C}\right)$.

According to available field data [39], the Arctic subsea permafrost (e.g., that in the Laptev shelf) has low salinity, and the gas hydrates it stores may dissociate rapidly even upon minor warming. The critical temperature in non-saline sediments was predicted to be as low as $t_{d}=-0.3^{\circ} \mathrm{C}$, while the Laptev shelf permafrost may become $0.5^{\circ} \mathrm{C}$ warmer already in a few decades [26,62]. Thus, warming of subsea permafrost in the Arctic shelf to $-0.5^{\circ} \mathrm{C}$ to $-1{ }^{\circ} \mathrm{C}$ may trigger large-scale gas hydrate dissociation in the near future. The possibility of violent methane release from bottom sediments poses risks of geohazard and negative environmental impacts. 


\section{Conclusions}

Dissociation of gas hydrates in the subsea permafrost that formed during regression is one of possible causes of active methane emission in the Arctic shelf. The intrapermafrost gas hydrates became destabilized at a high sea stand, when hydrate-bearing permafrost underwent rapid degradation upon interaction with sea water which led to large-scale release of methane into the air.

The experimental study of the process in laboratory shows that active dissociation of intrapermafrost gas hydrates starts at some critical temperature depending on sediment lithology and salinity. The dissociation of metastable relict gas hydrates in frozen sediments exposed to warming begins and ends slightly before the onset of pore ice melting. The critical temperature sufficient for triggering pore hydrate dissociation in permafrost ranges from $-3.0^{\circ} \mathrm{C}$ to $-0.3{ }^{\circ} \mathrm{C}$, i.e., the active process may begin even at small increase of the negative temperature of frozen sediments. Taking into account an almost gradientless temperature field during the subsea permafrost degradation, large-scale dissociation of gas hydrates accompanied by active gas emission and methane bubbling detectable in water can be expected in the near future.

Thus, the theoretical calculations and the physical modeling predict that minor warming of subsea permafrost poses risks of hazardous dissociation of metastable gas hydrates in the Arctic shelf.

Author Contributions: Conceptualization, experimental methodology, supervision, E.C.; carry out experiments, E.C., B.B., and D.D.; processing and analysis, E.C., D.D., and V.E.; writing manuscript and editing, E.C., D.D., V.E., B.B., N.S., and I.S.

Funding: The research was supported by the Russian Science Foundation (grants No. 16-17-00051, 18-77-10063, and 15-17-20032), the Russian Foundation for Basic Research (grant No. 17-05-00995), the Russian government (\#14, Z50.31.0012/03.19.2014), and Tomsk Polytechnic University (Competitiveness Enhancement Program grant, Project Number TPU CEP_SESE-299\2019).

Acknowledgments: The authors acknowledge engineer S.Grebenkin (Skoltech) for technical support of experiments.

Conflicts of Interest: The authors declare no conflict of interest.

\section{References}

1. Grigoriev, N.F. Permafrost in the Seaside Zone of Yakutia (Published in Russian); Nauka: Moscow, Russia, 1966; p. 180.

2. Wood, W.T.; Gettrust, J.F.; Chapman, N.R.; Spence, G.D.; Hyndman, R.D. Decreased Stability of Methane Hydrates in Marine Sediments Owing to Phase-Boundary Roughness. Nature 2002, 420, 656-660. [CrossRef] [PubMed]

3. Shakhova, N.E.; Nicolsky, D.Y.; Semiletov, I.P. Current State of Subsea Permafrost on the East Siberian Shelf: Tests of Modeling Results Based on Field Observations. Dokl. Earth Sci. 2010, 429, 1518-1521. [CrossRef]

4. Shakhova, N.; Semiletov, I.; Gustafsson, O.; Sergienko, V.; Lobkovsky, L.; Dudarev, O.; Tumskoy, V.; Grigoriev, M.; Chernykh, D.; Koshurnikov, A.; et al. Current Rates and Mechanisms of Subsea Permafrost Degradation in the East Siberian Arctic Shelf. Nat. Commun. 2017, 8, 15872:1-15872:13. [CrossRef] [PubMed]

5. Yusupov, V.I.; Salyuk, A.N.; Karnaukh, V.N.; Semiletov, I.P.; Shakhova, N.E. Detection of Areas of Methane Bubble Discharge on the Laptev Sea Shelf in the Eastern Arctic (Published in Russian). Rep. Acad. Sci. 2010, $430,820-823$.

6. Anisimov, O.A.; Borzenkova, I.I.; Lavrov, S.A.; Strelchenko, Y.G. Modern Dynamics of Underwater Permafrost and Methane Emission on the Shelf of the Seas of the Eastern Arctic (Published in Russian). Ice Snow 2012, 2, 97-105.

7. Loktev, A.; Bondarev, V.; Kulikov, S.; Rokos, S. Russian Arctic Offshore Permafrost. In Offshore Site Investigation and Geotechnics: Integrated Technologies—Present and Future; Society of Underwater Technology: London, UK, 2012; pp. 1-8. 
8. Sergienko, V.I.; Lobkovskii, L.I.; Semiletov, I.P.; Dudarev, O.V.; Dmitrievskii, N.N.; Shakhova, N.E.; Romanovskii, N.N.; Kosmach, D.A.; Nikol'skii, D.N.; Nikiforov, S.L.; et al. The Degradation of Submarine Permafrost and the Destruction of Hydrates on the Shelf of East Arctic Seas as a Potential Cause of the Methane Catastrophe: Some Results of Integrated Studies in 2011. Dokl. Earth Sci. 2012, 446, 1132-1137. [CrossRef]

9. Anisimov, O.A.; Kokorev, V.A. Comparative Analysis of Land, Marine, and Satellite Observations of Methane in the Lower Atmosphere in the Russian Arctic under Conditions of Climate Change. Izv. Atmos. Ocean. Phys. 2015, 51, 979-991. [CrossRef]

10. Koloskov, E.N.; Firsov, Y.G. The Use of Modern Hydrographic Technologies for the Study of Topography and Bottom Gas Occurrence in the Northern Seas of Russia (Published in Russian). Bull. State Univ. Marit. River Fleet Admiral SB Makarov 2015, 3, 54-62.

11. James, R.H.; Bousquet, P.; Bussmann, I.; Haeckel, M.; Kipfer, R.; Leifer, I.; Niemann, H.; Ostrovsky, I.; Piskozub, J.; Rehder, G.; et al. Effects of Climate Change on Methane Emissions from Seafloor Sediments in the Arctic Ocean: A Review. Limnol. Oceanogr. 2016, 61, S283-S299. [CrossRef]

12. Leifer, I.; Chernykh, D.; Shakhova, N.; Semiletov, I. Sonar Gas Flux Estimation by Bubble Insonification: Application to Methane Bubble Flux from Seep Areas in the Outer Laptev Sea. Cryosphere 2017, 11, 1333-1350. [CrossRef]

13. Thornton, B.F.; Geibel, M.C.; Crill, P.M.; Humborg, C.; Mörth, C.M. Methane Fluxes from the Sea to the Atmosphere across the Siberian Shelf Seas. Geophys. Res. Lett. 2016, 43, 5869-5877. [CrossRef]

14. Andreassen, K.; Hubbard, A.; Winsborrow, M.; Patton, H.; Vadakkepuliyambatta, S.; Plaza-Faverola, A.; Gudlaugsson, E.; Serov, P.; Deryabin, A.; Mattingsdal, R.; et al. Massive Blow-out Craters Formed by Hydrate-Controlled Methane Expulsion from the Arctic Seafloor. Science 2017, 356, 948-953. [CrossRef] [PubMed]

15. Sparrow, K.J.; Kessler, J.D.; Southon, J.R.; Garcia-Tigreros, F.; Schreiner, K.M.; Ruppel, C.D.; Miller, J.B.; Lehman, S.J.; Xu, X. Limited Contribution of Ancient Methane to Surface Waters of the U.S. Beaufort Sea Shelf. Sci. Adv. 2018, 4, eaao4842:1-eaao4842:7. [CrossRef] [PubMed]

16. Serov, P.; Portnov, A.; Mienert, J.; Semenov, P.; Ilatovskaya, P. Methane Release from Pingo-like Features across the South Kara Sea Shelf, an Area of Thawing Offshore Permafrost. J. Geophys. Res. F Earth Surf. 2015, 120, 1515-1529. [CrossRef]

17. Vonk, J.E.; Tank, S.E.; Bowden, W.B.; Laurion, I.; Vincent, W.F.; Alekseychik, P.; Amyot, M.; Billet, M.F.; Canario, J.; Cory, R.M.; et al. Reviews and Syntheses: Effects of Permafrost Thaw on Arctic Aquatic Ecosystems. Biogeoscience 2015, 12, 10719-10815. [CrossRef]

18. Lobkovskiy, L.I.; Nikiforov, S.L.; Dmitrevskiy, N.N.; Libina, N.V.; Semiletov, I.P.; Ananiev, R.A.; Meluzov, A.A.; Roslyakov, A.G. Gas Extraction and Degradation of the Submarine Permafrost Rocks on the Laptev Sea Shelf. Oceanology 2015, 55, 283-290. [CrossRef]

19. Ostanin, I.; Anka, Z.; di Primio, R. Role of Faults in Hydrocarbon Leakage in the Hammerfest Basin, SW Barents Sea: Insights from Seismic Data and Numerical Modelling. Geosciences 2017, 7, 28. [CrossRef]

20. Baranov, B.V.; Lobkovsky, L.I.; Dozorova, K.A.; Tsukanov, N.V. The Fault System Controlling Methane Seeps on the Shelf of the Laptev Sea. Dokl. Earth Sci. 2019, 486, 571-574. [CrossRef]

21. Shakhova, N.; Semiletov, I.; Salyuk, A.; Yusupov, V.; Kosmach, D.; Gustafsson, Ö. Extensive Methane Venting to the Atmosphere from Sediments of the East Siberian Arctic Shelf. Science 2010, 327, 1246-1250. [CrossRef]

22. Romanovskii, N.N.; Hubberten, H.W.; Gavrilov, A.V.; Eliseeva, A.A.; Tipenko, G.S. Offshore Permafrost and Gas Hydrate Stability Zone on the Shelf of East Siberian Seas. Geo-Marine Lett. 2005, 25, 167-182. [CrossRef]

23. Burwicz, E.; Rüpke, L.; Wallmann, K. Estimation of the Global Amount of Submarine Gas Hydrates Formed via Microbial Methane Formation Based on Numerical Reaction-Transport Modeling and a Novel Parameterization of Holocene Sedimentation. Geochim. Cosmochim. Acta 2011, 75, 4562-4576. [CrossRef]

24. Perlstein, G.Z.; Sergeev, D.O.; Tipenko, G.S.; Tumskoy, V.E.; Khimenkov, A.N.; Vlasov, A.N.; Merzlyakov, V.P.; Stanilovskaya, Y.V. Hydrocarbon Gases and Cryolithozone of the Arctic Shelf (Published in Russian). Arct. Ecol. Econ. 2015, 2, 35-44.

25. Ruppel, C.D.; Kessler, J.D. The Interaction of Climate Change and Methane Hydrates. Rev. Geophys. 2017, 55, 126-168. [CrossRef]

26. Shakhova, N.; Semiletov, I.; Chuvilin, E. Understanding the Permafrost-Hydrate System and Associated Methane Releases in the East Siberian Arctic Shelf. Geosciences 2019, 9, 251. [CrossRef] 
27. Sloan, E.D. Clathrate Hydrates of Natural Gases, Second Edition, Revised and Expanded; CRC Press: New York, NY, USA, 1998; p. 705. ISBN 9780824799373.

28. Koh, C.A.; Sloan, E.D.; Sum, A.K.; Wu, D.T. Fundamentals and Applications of Gas Hydrates. Annu. Rev. Chem. Biomol. Eng. 2011, 2, 237-257. [CrossRef]

29. Max, M. Natural Gas Hydrate In Oceanic and Permafrost Environments; Kluwer Academic Publishers: Washington, WA, USA, 2000; p. 419. ISBN 978-1-4020-1362-1. [CrossRef]

30. Solov'ev, V.A.; Ginsburg, G.D. Submarine Gas Hydrates (Published in Russian); VNII Oceanologii: St Petersburg, Russia, 1994; p. 194. ISBN 5-7173-0290-8.

31. Max, M.D.; Johnson, A.H.; Dillon, W.P. Natural Gas Hydrate-Arctic Ocean Deepwater Resource Potential; Springer: Dordrecht, The Netherlands, 2013; p. 113. ISBN 9783319025070. [CrossRef]

32. Chuvilin, E.; Bukhanov, B.; Davletshina, D.; Grebenkin, S.; Istomin, V. Dissociation and Self-Preservation of Gas Hydrates in Permafrost. Geosciences 2018, 8, 431. [CrossRef]

33. Chuvilin, E.; Ekimova, V.; Bukhanov, B.; Grebenkin, S.; Shakhova, N.; Semiletov, I. Role of Salt Migration in Destabilization of Intra Permafrost Hydrates in the Arctic Shelf: Experimental Modeling. Geosciences 2019, 9 , 188. [CrossRef]

34. Loktev, A.; Tokarev, M.; Chuvilin, E. Problems and Technologies of Offshore Permafrost Investigation. Proced. Eng. 2017, 189, 459-465. [CrossRef]

35. Chuvilin, E.; Bukhanov, B.; Tymskoy, V.; Shakhova, N.; Dudarev, O.; Semiletov, I. Thermal Conductivity of Bottom Sediments in the Area of Buor-Haya Bay (Laptev Sea Shelf) (Published in Russian). Earth's Cryosph. 2013, XVII, 24-36.

36. Romanovskii, N.N.; Gavrilov, A.V.; Tumskoy, V.E.; Kholodov, A.L.; Siegert, C.; Hubberten, H.W.; Sher, A.V. Environmental Evolution in the Laptev Sea Region during Late Pleistocene and Holocene. Polarforschung 2000, 68, 237-245.

37. Romanovskii, N.N.; Hubberten, H.W. Results of Permafrost Modelling of the Lowlands and Shelf of the Laptev Sea Region, Russia. Permafr. Periglac. Process. 2001, 12, 191-202. [CrossRef]

38. Nicolsky, D.; Shakhova, N. Modeling Sub-Sea Permafrost in the East Siberian Arctic Shelf: The Dmitry Laptev Strait. Environ. Res. Lett. 2010, 5, 015006. [CrossRef]

39. Nicolsky, D.J.; Romanovsky, V.E.; Romanovskii, N.N.; Kholodov, A.L.; Shakhova, N.E.; Semiletov, I.P. Modeling Sub-Sea Permafrost in the East Siberian Arctic Shelf: The Laptev Sea Region. J. Geophys. Res. Earth Surf. 2012, 117, F03028. [CrossRef]

40. Romanovskii, N.N.; Tumskoi, V.E. Retrospective Approach to the Estimation of the Contemporary Extension and Structure of the Shelf Cryolithozone in East Arctic (Published in Russian). Earth's Cryosph. 2011, 15, 3-14.

41. Overduin, P.P.; Schneider von Deimling, T.; Miesner, F.; Grigoriev, M.N.; Ruppel, C.; Vasiliev, A.; Lantuit, H.; Juhls, B.; Westermann, S. Submarine Permafrost Map in the Arctic Modeled Using 1-D Transient Heat Flux (SuPerMAP). J. Geophys. Res. Ocean. 2019. [CrossRef]

42. Romanovskii, N.N.; Eliseeva, A.A.; Gavrilov, A.V.; Tipenko, G.S.; Hubberten, X. The Long-Term Dynamics of Frozen Strata and the Zone of Gas Hydrate Stability in the Rift Structures of the Arctic Shelf of Eastern Siberia (Report 2) (Published in Russian). Earth's Cryosph. 2006, 10, 29-38.

43. Delisle, G. Temporal Variability of Subsea Permafrost and Gas Hydrate Occurrences as Function of Climate Change in the Laptev Sea, Siberia. Polarforschung 2000, 68, 221-225.

44. Mazarovich, A.O. Real and Potential Geological Hazards on the Ocean Floor, Slopes, and Shelf. Her. Russ. Acad. Sci. 2012, 82, 320-325. [CrossRef]

45. Sahling, H.; Römer, M.; Pape, T.; Bergès, B.; dos Santos Fereirra, C.; Boelmann, J.; Geprägs, P.; Tomczyk, M.; Nowald, N.; Dimmler, W.; et al. Gas Emissions at the Continental Margin West of Svalbard: Mapping, Sampling, and Quantification. Biogeosciences 2014, 11, 6029-6046. [CrossRef]

46. Bondur, V.G.; Kuznetsova, T.V.; Vorobyev, V.E.; Zamshin, V. Detection of Gas Shows on the Russian Shelf Based on Satellite Imagery Data (Published in Russian). Georesour. Geoenergy Geopolit. 2014, 1, 1-23.

47. Paull, C.K.; Ussler, W.; Dallimore, S.R.; Blasco, S.M.; Lorenson, T.D.; Melling, H.; Medioli, B.E.; Nixon, F.M.; McLaughlin, F.A. Origin of Pingo-like Features on the Beaufort Sea Shelf and Their Possible Relationship to Decomposing Methane Gas Hydrates. Geophys. Res. Lett. 2007, 34, L01603:1-L01603:5. [CrossRef]

48. Biastoch, A.; Treude, T.; Rpke, L.H.; Riebesell, U.; Roth, C.; Burwicz, E.B.; Park, W.; Latif, M.; Böning, C.W.; Madec, G.; et al. Rising Arctic Ocean Temperatures Cause Gas Hydrate Destabilization and Ocean Acidification. Geophys. Res. Lett. 2011, 38, 8. [CrossRef] 
49. Mau, S.; Romer, M.; Torres, M.E.; Bussmann, I.; Pape, T.; Damm, E.; Geprags, P.; Wintersteller, P.; Hsu, C.W.; Loher, M.; et al. Widespread Methane Seepage along the Continental Margin off Svalbard-From Bjornoya to Kongsfjorden. Sci. Rep. 2017, 7, 42997:1-42997:13. [CrossRef]

50. Westbrook, G.K.; Thatcher, K.E.; Rohling, E.J.; Piotrowski, A.M.; Pälike, H.; Osborne, A.H.; Nisbet, E.G.; Minshull, T.A.; Lanoisellé, M.; James, R.H.; et al. Escape of Methane Gas from the Seabed along the West Spitsbergen Continental Margin. Geophys. Res. Lett. 2009, 36, L15608. [CrossRef]

51. Majorowicz, J.A.; Hannigan, P.K. Natural Gas Hydrates in the Offshore Beaufort-Mackenzie Basin-Study of a Feasible Energy Source II. Nat. Resour. Res. 2000, 9, 201-214. [CrossRef]

52. Bogoyavlensky, V.; Kishankov, A.; Yanchevskaya, A.; Bogoyavlensky, I. Forecast of Gas Hydrates Distribution Zones in the Arctic Ocean and Adjacent Offshore Areas. Geosciences 2018, 8, 453. [CrossRef]

53. Moridis, G.J.; Collett, T.S.; Dallimore, S.R.; Satoh, T.; Hancock, S.; Weatherill, B. Numerical Studies of Gas Production from Several CH4 Hydrate Zones at the Mallik Site, Mackenzie Delta, Canada. J. Pet. Sci. Eng. 2004, 43, 219-238. [CrossRef]

54. Overduin, P.; Liebner, S.; Knoblauch, C.; Kneier, F.; Günther, F.; Schirrmeister, L.; Wetterich, S. Subsea Permafrost Degradation and Inferred Methane Release in Shallow Coastal Water of the Central Laptev Sea. In Proceeding of PERGAMON Final Symposium, Kiel, Germany, 4-7 November 2013.

55. Chuvilin, E.; Davletshina, D. Formation and Accumulation of Pore Methane Hydrates in Permafrost: Experimental Modeling. Geosciences 2018, 8, 467. [CrossRef]

56. GOST 12536-2014 Soils. Laboratory Determination of the Grain (Grain-Size) and Microaggregate Composition (Publsihed in Russian); Standartinform: Moscow, Russia, 2014.

57. Chuvilin, E.; Bukhanov, B. Effect of Hydrate Formation Conditions on Thermal Conductivity of Gas-Saturated Sediments. Energy Fuels 2017, 31, 5246-5254. [CrossRef]

58. Yakushev, V.S.; Semenov, A.P.; Bogoyavlensky, V.I.; Medvedev, V.I.; Bogoyavlensky, I.V. Experimental Modeling of Methane Release from Intrapermafrost Relic Gas Hydrates When Sediment Temperature Change. Cold Reg. Sci. Technol. 2018, 149, 46-50. [CrossRef]

59. Denisov, S.N.; Arzhanov, M.M.; Eliseev, A.V.; Mokhov, I. Assessing the Response of the Subanalytic Methane. Rep. Acad. Sci. 2011, 441, 685.

60. Romanovskii, N.N.; Hubberten, H.W.; Gavrilov, A.V.; Eliseeva, A.A.; Tipenko, G.S.; Kholodov, A.L.; Romanovsky, V.E. Permafrost and Gas Hydrate Stability Zone Evolution on the Eastern Part of the Eurasia Arctic Sea Shelf in the Middle Pleistocene-Holocene (Published in Russian). Earth's Cryosph. 2003, 7, 51-64.

61. Tipenko, G.S.; Romanovsky, N.N.; Kholodov, A.L. Modeling the Dynamics of the Submarine Cryolithozone and the Zone of Stability of Gas Hydrates: A Mathematical Solution, Numerical Implementation and the Results of Test Calculations (Published in Russian). Earth's Cryosph. 1999, 3, 71-78.

62. Malakhova, V.V. Mathematical Modeling of the Long-Term Dynamics of the Submarine Permafrost of the Arctic Shelf (Published in Russian). Interexpo Geo-Siberia 2014, 4, 1:1-1:5.

63. Malakhova, V.V.; Golubeva, E.; Eliseev, A.V.; Platov, G. Arctic Ocean Estimation of Possible Climate Change Impact on Methane Hydrate in the Arctic Ocean. IOP Conf. Ser. Earth Environ. Sci. 2018, 211. [CrossRef]

(C) 2019 by the authors. Licensee MDPI, Basel, Switzerland. This article is an open access article distributed under the terms and conditions of the Creative Commons Attribution (CC BY) license (http://creativecommons.org/licenses/by/4.0/). 